\title{
SAWERIGADING
}

Volume 24

No. 1, Juni 2018

Halaman 21-31

\section{PERNYATAAN WAKTU BERBENTUK FRASA DALAM BAHASA BUGIS (Deictic Phrase in Buginese Language)}

\author{
Syamsul Rijal \\ Balai Bahasa Sulawesi Selatan \\ Jalan Sultan Alauddin Km 7, Tala Salapang Makassar 90221 \\ Telepon (0411) 882401, Faksimile (0411) 882403 \\ Pos-el:anchuaziz@gmail.com
}

Diterima: 16 Oktober 2017; Direvisi: 4 Mei 208; Disetujui: 4 Mei 2018

\begin{abstract}
The purpose of this research is to describe deictic phrase in Buginese language. The method used is descriptive method by using note and constituend recording technique. In addition, documentation analysis of some texts of Buginese research and literary was also conducted. The theory used in data analysis is structural linguistic theory. The result shows that deictic phrase in Buginese language has constitued based on the type of constructions, namely endocentric phrase and exocentric phrase. Both have different components or constituens, either in the relationship of its constituens element or of its syntactic behavior.
\end{abstract}

Keywords: sintax; deictic; endocentric and exocentric phrase; Buginese language

Abstrak

Tujuan penelitian ini mendeskripsikan pernyataan waktu berbentuk frasa dalam bahasa Bugis. Metode yang digunakan adalah metode deskriptif dengan teknik pencatatan dan perekaman. Selain itu, dilakukan pula analisis dokumentasi dari berbagai naskah penelitian bahasa dan sastra Bugis. Teori yang digunakan dalam analisis data adalah teori linguistik struktural. Hasil penelitian menunjukkan bahwa pernyataan waktu bentuk frasa dalam bahasa Bugis memiliki pembentukan berdasarkan tipe konstruksinya, yakni frasa endosentris dan frasa eksosentris. Keduanya memiliki komponen atau unsur pembentuk yang berbeda, baik dari segi hubungan antarunsur-unsur pembentuknya maupun dari segi perilaku sintaksisnya.

Kata kunci: sintaksis; pernyataan waktu; frasa endosentris dan eksosentris; Bahasa Bugis

\section{PENDAHULUAN}

Kehadiran pernyataan waktu dapat menginformasikan kepada lawan bicara, sejak kapan, sampai kapan, atau berapa lama suatu tindakan, peristiwa, atau kejadian terjadi atau dilakukan yang terungkap dalam kalimat (Wijana, 1987: 1). Dalam bahasa Bugis, ada sejumlah leksem yang berfungsi sebagai pernyataan waktu. Namun, tidak semua leksem itu bersifat deiktis. Leksem elek 'pagi, esso 'siang', araweng 'sore', dan wenni 'malam', misalnya, tidak bersifat deiktis karena perbedaan tiap-tiap leksem itu ditentukan berdasarkan patokan posisi planet bumi terhadap matahari. Suatu leksem bersifat deiktis bila yang menjadi patokan adalah si pembicara (lihat juga Kaswanti Purwo, 1984:71). Kata baja 'besok', misalnya, adalah leskem yang bersifat deiktis. Kata baja 'besok', itu memiliki titik labuh satu hari sesudah tuturan.

Berbagai cara yang biasa dinyatakan untuk mengungkapkan waktu. Pengguna bahasa dapat menyatakan secara leksikal atau gramatikal dan banyak pula yang menyatakan secara leksikal saja. Perubahan bentuk verba sebagai penanda kala (tense) pada bahasa- 
bahasa yang mengungkapkan pernyataan waktu secara gramatikal akan menginformasikan apakah tindakan, peristiwa atau keadaan itu berlangsung pada waktu yang lalu, sekarang atau pada waktu yang akan datang. Penanda waktu seperti itu tidak ada dalam bahasa Bugis. Bahasa Bugis mengungkapkan lokasi waktunya dengan menggunakan penanda-penanda leksikal berupa kata, fasa atau klausa yang secara sintaktik menduduki fungsi keterangan. Tulisan yang pernah dilakukan sebelumnya adalah pernyataan waktu bentuk monomorfemik dan polimorfemik dalam bahasa Bugis (lihat Rijal, 2016). Oleh karena itu, perlu dilakukan penelitian tentang unsur-unsur leksikal yang dapat menyatakan waktu berbentuk frasa dalam bahasa Bugis.

Berdasarkan kenyataan tersebut, masalah pokok yang dibahas dalam penelitian ini adalah sebagai berikut.

1) Bagaimana pernyataan waktu bentuk frasa dalam bahasa Bugis?

2) Bagaimana pernyataan waktu bentuk frasa itu diungkapkan dalam bahasa Bugis?

3) Bagaimana pernyataan waktu bentuk frasa itu menghubungkan waktu situasi yang ditunjuknya dengan waktu-waktu yang lain?

\section{KERANGKA TEORI}

Linguistik struktural merupakan kerangka teori yang dipilih sebagai dasar analisis dalam penelitian ini. Strukturalisme berpandangan bahwa hubungan antara unsur-unsur bahasa lebih penting daripada unsur-unsur itu sendiri, dan satu-satunya objek linguistik yang sahih ialah sistem bahasa (Kridalaksana, 2008: 228).

Sama halnya dengan bahasa Indonesia, bahasa Bugis tidak memiliki tense 'kala' sebagai salah satu alat untuk menyatakan temporal deiktis secara gramatikal. Pengungkapan pernyataan waktu dalam bahasa Bugis biasanya dilakukan dengan adverbia temporal (bandingkan Djajasudarma dalam Wijana,1987: 10). Untuk mengungkapkan lokasi waktunya digunakan kata, frasa, atau klausa yang secara sintaksis menduduki fungsi keterangan (keterangan waktu). Jenis frasa merujuk pada pendapat Alwi (1998: 158) dan Putrayasa (2010: 7). Kridalaksana (2008: 121) menyatakan bahwa keterangan waktu merupakan bagian klausa yang menyatakan waktu terjadinya predikat, yaitu yang bersangkutan dengan bilamana, berapa lama, jangka lamanya, kekerapannya, sejak, dan sampai kapan.

Ramlan dalam Wijana (1987: 4--5) menyatakan bahwa pernyataan waktu dapat dijelaskan dalam dua tataran yang terpisah, yakni tataran fungsional dan tataran klausa. Pada tataran fungsional pernyataan waktu berwujud kata atau frasa yang menduduki fungsi keterangan yang menyatakan makna waktu, seperti kemarin, besok pagi, dan hari ini. Pernyataan waktu pada tataran klausal berwujud klausa bukan inti pada kalimat majemuk tidak setara. Klausa ini bisanya ditandai dengan kata penghubung yang menyatakan pertalian waktu. Kata penghubung itu, antara lain, ketika, tatkala, sejak, sebelum, hingga dan sesudah. Lebih lanjut diuraikan pula bahwa secara semantis 'waktu' suatu peristiwa dibedakan atas waktu terjadinya, waktu permulaan, dan waktu berakhiranya peristiwa atau keadaan.

\section{METODE}

Metode dasar yang diterapkan dalam penelitian ini adalah metode deskriptif. Metode ini berusaha untuk menemukan dan mencatat data yang berkaitan dengan objek yang diteliti. Deskripsi yang berdasarkan data diusahakan sampai kepada interpretasi kualitatifnya.

Sesuai dengan metode serta objek sasaran penelitian, yaitu pernyataan waktu berbentuk frasa dalam bahasa bugis, penelitian ini menggunakan teknik dokumentasi. Peneliti lebih banyak mengambil data dari pustaka bahasa dan sastra Bugis yang ditulis oleh Fachruddin (1981) dan Mulya (1996). Telaah pustaka ini dilakukan dengan cara mengumpulkan, kemudian mengklasifikasi, mendeskripsi pernyataan waktu bentuk frasa dalam bahasa Bugis. 


\section{PEMBAHASAN}

Pernyataan waktu bentuk frasa berdasarkan tipe konstruksi dibedakan menjadi dua macam, yakni frasa endosentris dan frasa eksosentris. Berikut dijelaskan satu per satu.

\section{Frasa Endosentris}

Frasa endosentris adalah kelompok kata yang berdistribusi pararel dengan salah satu atau semua unsur langsung. Contohnya frasa baja élék 'besok pagi' dan arawéng yaréga wenni 'sore atau malam' dalam kalimat (1) dan (2).

(1) Utajeko baja élék.

'kutunggu kamu besok pagi'

'Saya menunggu kamu besok pagi.'

(2) Arawéng yaréga wenni tassir untuk paimeng.

'soreatau malam kita bertemu lagi

'Sore atau malam kita bertemu lagi.'

Rangkaian baja élék contoh (1) memiliki distribusi yang sama dengan baja, rangkaian arawéng yaréga wenni contoh (2) memiliki distribusi yang sama dengan arawéng dan wenni. Persamaan distribusi itu dapat dilihat dalam kalimat (3) dan (4).

\section{(3) Utajekko baja.}

'kutunggu kamu besok'

'Saya menunggu kamu besok.'

$$
\begin{gathered}
\left\{\begin{array}{l}
\text { a. araweng 'sore' } \\
\text { b. weni 'malam' }
\end{array}\right\} \begin{array}{l}
\text { tasiruntuk paimeng. } \\
\text { 'kita bertemu lagi' }
\end{array} \\
\left\{\begin{array}{l}
\text { a. Sore } \\
\text { b. Malam }
\end{array}\right\} \text { kita bertemu lagi. }
\end{gathered}
$$

Berdasarkan sifat hubungan antarunsurunsur langsungnya, pernyataan waktu yang berbentuk frasa endosentris dibedakan menjadi tiga golongan, yaitu frasa endosentris atributif, koordinatif, dan apositif.

\section{Frasa Endosentris Atributif}

Frasa endosentris atributif adalah satuan lingual yang salah satu unsur langsungnya mempunyai kedudukan yang lebih tinggi daripada unsur lainnya. Unsur langsung yang lebih tinggi kedudukan bertindak sebagai inti atau pusat dari satuan itu, sedangkan unsur lainnya merupakan atribut dari inti atau pusatnya. Frasa endosentris atributif yang menyatakan kala, seperti

$\begin{array}{ll}\text { baja élék } & \text { 'besok pagi', } \\ \text { esso Jumak } & \text { 'hari Jumat', } \\ \text { uleng Ramalang } & \text { 'bulan Ramadan', dan } \\ \text { wettu duriang } & \text { 'musim durian'. }\end{array}$

Contoh tersebut adalah frasa yang masingmasing terdiri atas dua unsur, yakni élék 'pagi', esso 'hari', uleng 'bulan', dan wettu 'musim' merupakan atribut, sedangkan baja 'besok', Jumak 'Jumat', Ramalang 'Ramadan', dan duriang 'durian' merupakan unsur pusat, yakni unsur yang secara distribusional sama dengan seluruh frasa, dan secara semantis merupakan unsur yang terpenting. Contoh kalimat berikut.

(4) Melokak lao ri pasaké baja élék.

'mau saya pergi di pasar besok pagi'

'Saya mau pergi ke pasar besok pagi.'

(5) Esso Jumat najaji anrinna.

'hari Jumatia lahir adiknya'

'Adiknya lahir pada hari Jumat.'

(6) Dekpa na wettu duriang ri kampokku.

'belum ia musim durian di kampungku'

'Belum musim durian di kampungku.'

Cook dalam Wijana (1987: 42) mengatakan bahwa unsur-unsur pembatas dalam frasa endosentris atributif cenderung bersifat opsional, hanya dalam konstruksi tertentu kehadirannya bersifat wajib. Hal seperti itu juga dapat dilihat dalam frasa endosentris atributif yang menyatakan waktu.

Unsur pewatas seperti élék 'pagi' contoh (5), esso 'hari'(contoh (6), merupakan atribut yang kehadirannya bersifat opsional.Oleh karena itu, kalimat (5)-(6) dapat diubah menjadi (5a) dan (6a) berikut.

(5a) Mélokak lao ripasa é baja élék. 'mau saya pergi ke pasar besok pagi' 'Saya mau pergi ke pasar besok.'

(6a) Jumak najaj i anrinna 'jumat ia lahir adiknya'

'Hari Jumat adiknya lahir.'

Unsur pewatas yang kehadirannya bersifat wajib adalah wettu 'musim' contoh (7). Dengan 
demikian, kalimat (7) tidak bergramatikal apabila diubah menjadi kalimat seperti berikut.

(8) *Dekpa na duriang ri kampokku.

'belum ia durian di kampungku'

'Belum durian di kampungku.'

Apabila dilihat dari unsur-unsur pembentukannya, pernyataan waktu berbentuk frasa endosentris atributif dapat dibedakan atas beberapa tipe sebagai berikut.

\section{Pernyataan Waktu Mengikuti Pronomina}

Pernyataan waktu yang berfungsi sebagai inti frasa (unsur pusat) dapat didahului oleh pronominal ia/iaé 'ini' dan iaro 'itu' yang berfungsi sebagai atribut. Unsur pusat itu dapat berupa leksem waktu kosmik, seperti esso 'hari', uleng 'bulan', taung 'tahun', dan sebagainya; frasa nomina kuantitatif, seperti Salasa 'Selasa', Kamisik 'Kamis'; nama bulan seperti Ramalang 'Ramadan', Sawaleng 'Syawal'; bagian hari seperti élék 'pagi', arawéng 'sore'; nama waktu salat seperti subu 'subuh', assarak 'asar'. Contohnya seperti (9) dan (10) berikut.

(9) $\left\{\begin{array}{l}\text { ia } \\ \text { iae } \\ \text { 'ini' }\end{array}\right\}\left\{\begin{array}{l}\text { esso é' } \\ \text { duangesso éc } \\ \text { elek e' }\end{array}\right\}\left\{\begin{array}{l}\text { hari' hari } \\ \text { dua hari' dua hari ini } \\ \text { 'pagi' pagi }\end{array}\right\}$

(10) $\left\{\begin{array}{l}\text { iaro } \\ \text { 'itu' }\end{array}\right\}\left\{\begin{array}{l}\text { esso é } \\ \text { duangesso e e } \\ \text { elek } \boldsymbol{e}^{6}\end{array}\right\}\left\{\begin{array}{l}\text { 'hari' hari } \\ \text { 'dua hari' dua hari itu } \\ \text { 'pagi'pagi }\end{array}\right\}$

Contoh penggunaannya dalam kalimat sebagai berikut.

(11) Dékpa na pole ia esso é.

'belum ia datang ini hari'

'Ia belum datang hari ini.'

(12) Iaro élék é polekak cemmé ri salok é.

'itu pagi datang saya mandi di sungai'

'Pagi itu saya pulang mandi dari sungai.'

Pernyataan waktu yang didahului pronomina contoh (9) dan (10) selalu diiringi oleh partikel é yang berfungsi sebagai penegas. Kehadiran partikel é dalam konstruksi itu bersifat wajib sehingga pelesapan partikel é menghasilkan konstruksi yang tidak berterima, seperti * ia (iae) esso.
(13) $\left\{\begin{array}{l}\text { ia } \\ \text { iae } \\ \text { 'ini' }\end{array}\right\}\left\{\begin{array}{l}* \text { esso'hari' } \\ * \text { duangesso 'dua hari' } \\ * \text { elek'pagi' }\end{array}\right\}\left\{\begin{array}{l}\text { hari } \\ \text { dua hari } \\ \text { pagi }\end{array}\right\}$

(14) $\left\{\begin{array}{l}\text { iaro } \\ \text { 'itu' }\end{array}\right\}\left\{\begin{array}{l}* \text { esso'hari' } \\ * \text { duangesso 'dua hari }\end{array}\right\}\left\{\begin{array}{l}\text { hari } \\ \text { dua hari }\end{array}\right\}$

\section{Pernyataan Waktu Diikuti Pronomina}

Pernyataan waktu dapat didahului pronomina (9) dan (10), dapat pula mendahului pronominal ewe 'ini' dan ero 'itu' (contoh (15)

(15) $\left\{\begin{array}{l}\text { esso 'hari' } \\ \text { élék } \\ \text { duangesso }\end{array}\right\}\left\{\begin{array}{l}\text { éwé } \\ \text { 'pagi' } \\ \text { 'dua hari' }\end{array}\right\}\left\{\begin{array}{l}\text { 'ini' } \\ \text { ero 'itu' }\end{array}\right\}$

Contoh penggunaanya dalam kalimat, seperti tampak pada (16) dan (17).

(16) Dékgaga bosi ri lalenna duang esso éwé.

'tidak adahujan di dalam dua hariini'

'Hujan tidak turun dalam dua hari ini.'

(17) Siruntukak ambokmu élék éro.

'bertemu saya bapakmu pagi tu'

'Pagi itu saya bertemu dengan bapakmu.'

\section{Pernyataan Waktu Diikuti Numeralia}

Pernyataan waktu sebagai unsur pusat pada frasa dapat diikuti oleh numeralia sebagai atributnya. Numeralia berfungsi sebagai nama leksem waktu kosmik yang diikutinya. Leksem waktu kosmik yang dimaksud adalah uleng 'bulan' dan taung 'tahun', seperti (18) berikut.

(18) uleng pitu 'bulan tujuh' (bulan Juli) uleng seppulo dua 'bulan dua belas' (bulan Desember) taung 1945 'tahun 1945'

Contoh penggunaannya dalam kalimat, seperti tampak pada (19) dan (20).

(19) Uleng pitu najaji anakku.

'bulan tujuh ia lahir anakku'

'Anak saya lahir pada bulan Juli.'

(20) Taung 1945 namaradeka Indonesia. 'tahun 1945 ia merdeka Indonesia 'Indonesia merdeka tahun 1945.' 


\section{Pernyataan Waktu Mengikuti Numeralia}

Pernyataan waktu sebagai unsur pusat pada frasa ini dapat mengikuti numeralia sebagai atributnya. Pernyataan waktu itu berupa leksem waktu kosmik, yakni jang 'jam', esso 'hari', minggu 'minggu', uleng 'bulan', taung 'tahun', élék 'pagi', arawéng 'sore', wenni 'malam'. Contohnya seperti berikut.
(21) $\left\{\begin{array}{l}\text { tellujjang } \\ \text { pitung esso } \\ \text { dua minggu }\end{array}\right\}$
$\left\{\begin{array}{l}\text { 'tiga jam' } \\ \text { 'tujuh hari' } \\ \text { 'dua minggu' }\end{array}\right\}$
(22) $\left\{\begin{array}{l}\text { dua élék } \\ \text { tellu arawéng } \\ \text { limampenni }\end{array}\right\}$
$\left\{\begin{array}{l}\text { 'dua pagi' } \\ \text { 'tiga sore' } \\ \text { 'lima malam' }\end{array}\right\}$

\section{Pernyataan Waktu Diikuti Leksem Ruang}

Leksem ruang seperti riolo 'silam', labek é 'lalu', mangolo é 'depan', dan paimeng 'mendatang' dapat menduduki fungsi atribut dalam frasa endosentris atributif yang menyatakan waktu. Leksem ruang yang mengungkapkan pengertian tentang gerak yang dihubungkan dengan waktu mempunyai dua acuan, yakni acuan ke depan atau menunjuk ke waktu lampau dan acuan ke depan atau menunjuk ke waktu yang akan datang (future).

Dalam bahasa Bugis apabila waktu digunakan mengacu ke depan (future), leksem ruang yang dipakai sebagai pernyataan waktu adalah rimonri 'di belakang', paimeng 'mendatang', mangolo é 'yang akan datang (depan)'. Leksem ruang ini dapat dirangkaikan dengan satuan kalender, seperti taung 'tahun', uleng 'bulan', nama hari: Sénéng 'Senin', Salasa 'Selasa', Araba 'Rabu', Kammisik 'Kamis', Jumak 'Jumat', Sattu 'Sabtu', dan Ahak 'Ahad' yang berfungsi sebagai inti frasa.

\section{Contoh:}

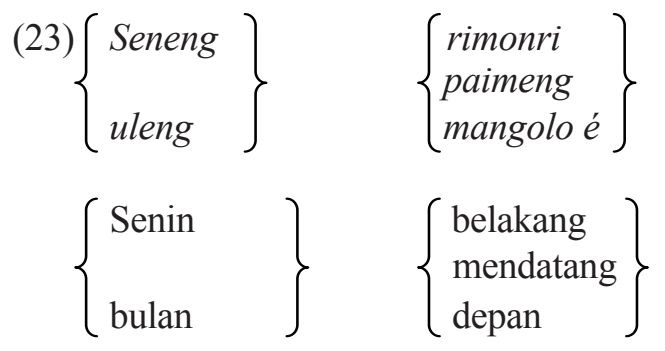

Contoh pemakaianya dalam kalimat dapat dilihat sebagai berikut.

(24) Sénéng (ri monri 'di belakang') mappuasanik. 'Senin' $\left\{\begin{array}{l}\text { paimeng 'mendatang' } \\ \text { mangoloe 'depan' }\end{array}\right\} \begin{aligned} & \text { berpuasa su- } \\ & \text { dah kita }\end{aligned}$

'Senin $\left\{\begin{array}{l}\text { belakang } \\ \text { mendatang } \\ \text { depan }\end{array}\right\}$ kita sudah berpuasa.'

Selain nama hari, nama bulan Hijriah dapat pula dirangkaikan dengan kata rimonri 'di belakang', paimeng 'mendatang', dan mangolo $\boldsymbol{e}$ ' 'depan' karena bersiklus; dalam perputaran waktu setiap kali dapat berulang lagi. Perhatikan contoh (25) berikut.

(25) \{

$\left\{\begin{array}{l}\text { uleng Muharrang } \\ \text { uleng Ramalang }\end{array}\right\}\left\{\begin{array}{l}\text { rimonri paimeng } \\ \text { mangolo é }\end{array}\right\}$
$\left\{\begin{array}{l}\text { 'bulan Muharam } \\ \text { 'bulan Ramadan }\end{array}\right\}\left\{\begin{array}{l}\text { di belakang mendatang' } \\ \text { depan' }\end{array}\right\}$

Untuk menyebut nama bulan Hijriah yang mengacu ke tahun depan, biasanya dirangkaikan dengan kata taung 'tahun'. Contohnya sebagai berikut.

(26)

$$
\begin{gathered}
\left\{\begin{array}{l}
\text { uleng Ramalang } \\
\text { uleng Sulehajji }
\end{array}\right\}\left\{\begin{array}{l}
\text { taung rimonri } \\
\text { taung paimeng } \\
\text { taung mangolo e }
\end{array}\right\} \\
\left\{\begin{array}{l}
\text { 'bulan Muharam } \\
\text { 'bulan Ramadan }
\end{array}\right\}\left\{\begin{array}{l}
\text { di belakang' } \\
\text { mendatang' } \\
\text { depan' }
\end{array}\right\}
\end{gathered}
$$

Dalam bahasa Bugis, nama bulan Masehi, seperti Januari, Februari, Maret, dan seterusnya tidak lazim digunakan dalam berkomunikasi. Sebagai gantinya dipakai nama angka atau bilangan, seperti uleng Seddi 'bulan Satu' untuk menyebutkan Januari, uleng Dua 'bulan Dua' untuk menyebut bulan Februari, dan seterusnya. Selain memakai bilangan dalam penyebutan nama bulan, sering pula digunakan nama bulan berdasarkan tahun Hijriah contoh (26).

Apabila waktu digunakan mengacu ke belakang atau menunjuk waktu lampau, leksem ruang yang dipakai sebagai pengungkap waktu adalah riolo 'di depan (dahulu)', labek é 'yang lampau'. Leksem waktu itu menduduki fungsi atribut yang mengikuti satuan kalender yang 
merupakan unsur pusatnya. Satuan kalender itu adalah minggu 'minggu', uleng 'bulan', taung 'tahun'; nama hari seperti Seneng 'Senin', Salasa 'selasa', Arabak 'Rabu' dan seterusnya; nama bulan seperti Muharang 'Muharam', Ramalang 'Ramadan', Sulehajji 'Zulhijah', dan seterusnya; uleng Seddi 'bulan Januari', uleng Dua 'bulan Februari', uleng Tellu 'bulan Maret' dan seterusnya; nama tahun seperti taung 1945 'tahun 1945'.

Satuan kalender yang dirangkaikan dengan leksem ruang dapat dilihat pada contoh berikut.

(27)

$$
\begin{aligned}
& \left\{\begin{array}{l}
\text { Ramalang } \\
\text { ulengSeddi } \\
\text { taung 2001 }
\end{array}\right\} \quad\left\{\begin{array}{l}
\text { riolo } \\
\text { labek é } \\
\text { lalo é }
\end{array}\right\} \\
& \left\{\begin{array}{l}
\text { 'Ramadan } \\
\text { 'Januari } \\
\text { 'tahun 2001 }
\end{array}\right\} \quad\left\{\begin{array}{l}
\text { (yang) dahulu' } \\
\text { (yang) lalu' } \\
\text { (yang) lampau' }
\end{array}\right\}
\end{aligned}
$$

Frasa nomina kuantitatif berupa satuan kalender dapat juga dirangkaikan dengan leksem ruang yang menunjuk pada waktu lampau contoh (28)

$$
\begin{aligned}
& \text { (28) }\left\{\begin{array}{l}
\text { dua minggu } \\
\text { ennenguleng } \\
\text { seppulo taung }
\end{array}\right\} \quad\left\{\begin{array}{l}
* \text { riolo } \\
\text { labek e } \\
\text { lalo e }
\end{array}\right\} \\
& \left\{\begin{array}{l}
\text { dua minggu } \\
\text { enam bulan } \\
\text { sepuluh tahun }
\end{array}\right\} \quad\left\{\begin{array}{l}
* \text { (yang) dahulu } \\
\text { (yang) lalu } \\
\text { (yang) lampau }
\end{array}\right\}
\end{aligned}
$$

Contoh (28) memperlihatkan bahwa leksem ruang riolo 'yang dahulu' tidak dapat dirangkaikan dengan ukuran waktu, tetapi dengan labek é 'yang lalu' dan lalo e 'yang lampau' dapat dirangkai.

\section{Pernyataan Waktu Diikuti Leksem Waktu}

Leksem waktu yang biasa menduduki fungsi atribut dalam frasa endosentris atributif yang menyatakan waktu adalah bagian hari, seperti élék 'pagi', esso 'hari', arawéng 'sore', wenni 'malam', dénnari 'dini hari', dan subu 'subuh'. Unsur pusat yang dapat hadir adalah pernyataan waktu berupa kata-kata yang dapat mengungkapkan kala absolut, seperti dénre 'tadi', onnang 'tadi', wennik 'kemarin', matuk 'nanti', baja 'besok'. Perhatikan contoh berikut.

(29)

$$
\left\{\begin{array}{l}
\text { denrek } \\
\text { onnang }
\end{array}\right\}\left\{\begin{array}{l}
\text { éléké } \\
\text { esso é } \\
\text { arawéng é }
\end{array}\right\} \text { tadi }\left\{\begin{array}{l}
\text { pagi’ } \\
\text { siang' } \\
\text { sore' }
\end{array}\right\}
$$

(30) wennik $\left\{\begin{array}{l}\text { élék é } \\ \text { esso é، } \\ \text { arawéng é }\end{array}\right\}$ 'kemarin $\left\{\begin{array}{l}\text { pagi' } \\ \text { siang' } \\ \text { sore' }\end{array}\right\}$

(31) wennik $\left\{\begin{array}{l}\text { élékna } \\ \text { essona' } \\ \text { arawénna }\end{array}\right\}$ 'kemarin $\left\{\begin{array}{l}\text { pagi' } \\ \text { siang' } \\ \text { sore' }\end{array}\right\}$

(32) matuk $\left\{\begin{array}{l}\text { koélék } i \\ \text { kotenngessoi } \\ \text { koarawénngi }\end{array}\right\}$ nanti $\left\{\begin{array}{l}\text { kalau pagi’ } \\ \text { kalau tengah hari } \\ \text { kalau sore' }\end{array}\right\}$

(33) baja $\left\{\begin{array}{l}\text { élék } \\ \text { tenngasso' } \\ \text { arawéng }\end{array}\right\}$ besok $\left\{\begin{array}{l}\text { pagi’ } \\ \text { tengah hari' } \\ \text { sore' }\end{array}\right\}$

(34) baja $\left\{\begin{array}{l}\text { élék é } \\ \text { tenngasso é } \\ \text { arawénngé }\end{array}\right\}$ 'besok $\left\{\begin{array}{l}\text { pagi’ } \\ \text { tengah hari' } \\ \text { sore' }\end{array}\right\}$

(35) baja $\left\{\begin{array}{l}\text { koélék-i } \\ \text { kotengngessoi } \\ \text { koarawénngi }\end{array}\right\}$ 'besok $\left\{\begin{array}{l}\text { pagi' } \\ \text { tengah hari' } \\ \text { sore' }\end{array}\right\}$

Bagian hari seperti élék 'pagi', esso 'siang', arawéng 'sore', wenni 'malam', dénnari 'dini hari', dan subu 'subuh' selalu diikuti partikel penegasan é apabila dirangkaikan dengan kata denrék' tadi' dan onnang 'tadi' contoh (29).

Apabila bagian hari dirangkaikan dengan kata wennik 'kemarin', partikel yang selalu muncul di belakangnya adalah partikel penegasan é contoh (30), atau partikel penegasan $n a$ contoh (31).

Jika bagian hari dirangkaikan dengan kata matuk 'nanti', bagian hari itu akan didahului oleh konjungtor ko (kependekan dari kata rékko 'kalau') dan diikuti oleh kata penegas $i$ atau wi, contoh (32).

Apabila bagian hari dirangkaikan dengan kata baja 'besok' dapat muncul tanpa diikuti partikel contoh (33), bagian itu dapat juga diikuti partikel penegas é contoh (34) atau didahului konjungtor $k o$ dan diikuti partikel penegas contoh (35) 


\section{Pernyataan Waktu Diikuti Adverbia}

Pernyataan waktu sebagai unsur pusat pada frasa ini dapat diikuti adverbia sennak atau laddek yang berarti 'sangat, terlalu, sekali'. Unsur pusat itu berupa nama bagian hari, élék 'pagi', wenni 'malam', subu'subuh'. Kata élék, wenni dan subu harus diberi awalan ma- menjadi maélék, mawenni, dan masubu, sebelum dirangkaikan dengan kata sennak atau laddek contoh (36).

$$
\begin{aligned}
& \text { (36) }\left\{\begin{array}{l}
\text { maélék } \\
\text { mawenni } \\
\text { masubu }
\end{array}\right\}\left\{\begin{array}{l}
\text { 'pagi' } \\
\text { 'malam' } \\
\text { 'subuh' }
\end{array}\right\}\left\{\begin{array}{l}
\text { sennak'terlalu' } \\
\text { laddek 'sangat' }
\end{array}\right\} \\
&\left\{\begin{array}{l}
\text { terlalu } \\
\text { sangat }
\end{array}\right\} \quad\left\{\begin{array}{l}
\text { pagi } \\
\text { malam } \\
\text { subuh }
\end{array}\right\}
\end{aligned}
$$

Rangkaian *maarawéng laddek 'sangat sore' tidak pernah terdengar atau terlihat dipergunakan; sebagai gantinya dipakai rangkaian mélokni mawenni 'menjelang malam'.

Selain kata sennakatau laddek, adverbia bujuruk 'suntuk' dapat juga dirangkaikan dengan leksem waktu, khususnya yang menyatakan lama waktu berlangsungnya suatu tindakan atau keadaan contoh (37).

$$
\text { (37) } \left.\begin{array}{r}
\text { siesso } \\
\text { siélék }
\end{array}\right\}\left\{\begin{array}{c}
\text { 'sehari' } \\
\text { 'sepagian' }\}
\end{array}\right\} \begin{aligned}
& \text { bujuruk' } \\
& \text { 'sepanjang }\left\{\begin{array}{l}
\text { hari' } \\
\text { pagi' }
\end{array}\right\}
\end{aligned}
$$

Kata bujuruk 'suntuk' pemakaiannya terbatas yang tidak melebihi jangka waktu satu hari atau satu malam. Rangkaian siesso bujuruk 'sehari suntuk' lokasi waktunya mulai setelah matahari terbit hingga matahari terbenam; siwenni bujuruk 'semalam suntuk' waktunya mulai matahari terbenam hingga matahari terbit; siélék bujuruk 'sepagian' waktunya mulai matahari terbit hingga menjelang siang hari (kira-kira pukul 11.00); siarawéng bujuruk 'sepanjang sore' waktunya mulai kira-kira dari pukul tiga sampai matahari terbenam.

\section{Pernyataan Waktu Mengikuti Adverbia}

Pernyataan waktu sebagai unsur pusat pada frasa ini dapat mengikuti adverbia puppuk 'suntuk'. Dalam menyatakan waktu, kata puppuk bersinonim dengan kata bujurukyang sudah dipaparkan di atas. Akan tetapi, dalam konstruksi dengan leksem waktu, kata puppuk letaknya mendahului leksem waktu sedangkan kata bujuruk mengikuti leksem waktu. Bandingkan contoh (37) dengan contoh (38) yang berikut.

$$
\begin{aligned}
& \text { puppuk }^{`} \text { suntuk' }\left\{\begin{array}{l}
\text { wenni'malam’ } \\
\text { araweng'sore’ }
\end{array}\right\} \\
& \text { 'sepanjang }\left\{\begin{array}{c}
\text { malam' } \\
\text { sore' }
\end{array}\right\}
\end{aligned}
$$

Selain letaknya berbeda, kata esso, wenni, élék, dan arawéng yang dirangkaikan dengan kata bujuruk harus diimbuhi awalan si-, tetapi jika dirangkaikan dengan kata puppuk, leksem waktu itu tidak diimbuhi awalan $s i$.

\section{Frasa Endosentris Koordinatif}

Pernyataan waktu ada yang dapat berkontruksi dengan frasa endosentris koordinatif. Frasa jenis ini memiliki dua unsur pusat atau lebih yang masing-masing berdistribusi pararel dengan keseluruhan frasa yang dibentuknya. Keparalelannya itu dibuktikan oleh kemungkinan unsur-unsur pusat itu dihubungkan dengan konjungtor koordinator sibawa 'dan' atau yaréga 'atau'. Perhatikan contoh berikut.

(39) Esso Arabak sibawa Ahak napasak Maroanging.

'hari Rabu dan Ahad ia pasar Maroangin' 'Hari Rabu dan Ahad adalah hari pekan di Maroangin.'

(40) Mappésauno jolok makjama siesso yaréga duangesso.

'berhentilah kamu dahulu bekerja sehari atau dua hari'

'Berhentilah dahulu kamu bekerja sehari atau dua hari.'

Frasa esso Arabak sibawa Ahakd dalam kalimat (39) dan siesso yaréga duangesso dalam kalimat (40) adalah frasa endosentris koordinatif. 
Frasa ini memiliki dua unsur pusat yang masingmasing memiliki kedudukan yang sama. Unsur esso Arabak dan Ahaq memiliki kedudukan yang sama satu sama lain karena keduanya dapat berdiri sendiri sebagai pusat. Sifat yang serupa juga dimiliki oleh unsur siesso dan duangesso dalam frasa siesso yaréga duang esso. Hal ini terbukti dengan keberterimaan kalimat (41) dan (42) berikut.

$$
\begin{gathered}
\text { (41) }\left\{\begin{array}{c}
\text { a. (Esso) Arabak } \\
\text { '(hari) Rabu' } \\
\text { b. (Esso) Ahak' } \\
\text { '(hari) Ahad' }
\end{array}\right\} \begin{array}{c}
\text { napasak Rappeng. } \\
\text { ia pasar Rappang }
\end{array} \\
\left\{\begin{array}{ll}
\text { a. (Hari) Rabu } \\
\text { b. (Hari) Ahad }
\end{array}\right\} \quad \begin{array}{l}
\text { adalah hari pekan } \\
\text { di Rappang. }
\end{array}
\end{gathered}
$$

(42) Mappésauno jolok makjama $\left.\begin{array}{l}\text { berhentilah kamu dahulu bekerja } \\ \text { siesso.' } \\ \text { sehari' }\end{array}\right\}$ $\left\{\begin{array}{l}\text { duang esso.' } \\ \text { 'dua hari' }\end{array}\right\}$ 'Berhentilah dahulu
kamu bekerja $\quad\left\{\begin{array}{l}\text { sehari.' } \\ \text { dua hari. }\end{array}\right\}$

Konjungtor yaréga 'atau' pada frasa endosentris koordinatif dapat dilesapkan apabila unsur pusatnya berupa kata atau frasa nominal kuantitatif yang menyatakan makna 'lama waktu'. Frasa duang esso yarega tellung esso 'dua hari atau tiga hari' dan patampuleng yaréga limampuleng 'empat bulan atau lima bulan' dapat diubah menjadi dua tellungesso 'dua tiga hari' dan patampuleng limampuleng'empat lima bulan'. Perhatikan contoh (43) dan (44).

(43) Mattajengik dua tellung esso. 'menunggu kita duatiga hari' 'Kita menunggu dua tiga hari.'

(44) Ripiarai jolok patampuleng limampuleng. 'dipelihara ia dahulu empat bulan lima bulan' 'Dipelihara dahulu empat lima bulan.'

Pelesapan konjungtor yaréga 'atau' tidak dapat dilakukan pada frasa yang bertipe endosentris koordinatif alternatif yang unsurunsurnya bukan berupa kata atau frasa nominal kuantitatif yang menyatakan lama waktu terjadinya peristiwa, keadaan, atau dilakukannya tindakan. Frasa makkukkuéyaréga baja 'sekarang atau besok', esso Jumak yaréga esso Ahak 'hari Jumat atau Ahad', dan sebagainya tidak dapat diubah menjadi *makkukuaé baja, dan *esso Jumak Ahak, seperti terlihat pada contoh (45) dan (46).

\section{(45) *Weddinno lisu makkukuaé baja. 'boleh sudah kamu pulang sekarangbesok' \\ 'Kamu sudah boleh pulang sekarang besok.' \\ (46) *Esso JumakAhak tasir untuk paimeng. 'hariJumatAhad kita bertemu lagi' 'Hari Jumat Ahad kita bertemu lagi.'}

\section{Frasa Endosentris Apositif}

Frasa endosentris apositif adalah frasa endosentris yang unsur-unsur langsungnya memiliki makna yang sama. Karena sama, unsur yang merupakan unsur pusat dapat diganti oleh unsur langsung lainnya yang merupakan aposisi. Frasa endosentris apositif yang menyatakan waktu dalam bahasa Bugis dapat dilihat pada contoh berikut.

\section{(47) Esso Arabak paimeng, tanggalak 28 ulen-garua, na botting.} 'hari Rabu mendatang, tanggal 28 bulan delapan ia pengantin'

'Hari Rabu akan datang, tanggal 28 Agustus, ia berpengantin.'

(48) Sangadi wennik, essonaSinéng é, natarakkak pammeka é.

'kemarin dulu, harinya Senin, ia berangkat jemaah haji

'Kemarin dulu, hari Senin, jamaah haji berangkat.'

Konstituen esso Arabak paimeng, tanggalak 28 ulengarua contoh (47)) dan sangadi wennik, essona Sinéng é contoh (48) adalah frasa endosentris apositif. Kedua frasa itu memiliki dua unsur langsung yang masing-masing memiliki makna yang sama secara ekstralingual. Dalam contoh (47) esso Arabak paimeng secara ekstra lingual memiliki referen yang sama dengan tanggalak 28 uleng arua. Demikian pula halnya konstituen sangadi wennik dalam 
contoh (48) memiliki referen yang sama secara ekstralingual dengan essonaSinéng é. Karena sama, unsur esso Arabak paimeng contoh (47) dapat diganti dengan unsur tanggalak 28 uleng Arua, unsur sangadi wennik contoh (48) dapat diganti dengan unsur essona Sinéng é.

\section{Frasa Eksosentris}

Frasa eksosentris adalah frasa yang sebagian atau seluruhnya tidak mempunyai perilaku sintaksis yang sama dengan komponenkomponennya. Frasa ini mempunyai dua komponen yang pertama disebut perangkai berupa preposisi atau partikel; yang kedua disebut sumbu berupa kata atau kelompok kata (Kridalaksana, 2008: 8). Frasa lettuk tennga benni'sampai tengah malam' contoh (49) dan (50) adalah frasa eksosentris.

(49) Makjamai lettuk tennga benni.

'bekerja ia sampai tengah malam'

'Ia bekerja sampai tengah malam.'

(50) Lettuk tennga benni maroak bottingéro.

'sampai tengah malam ramai pengantin itu'

'Pesta perkawinan itu ramai sampai tengah malam.'

Frasa lettuk tennga benni tidak berperilaku yang sama dengan komponen lettuk atau tennga benni. Oleh karena itu, kalimat (51) dan (52) berikut ini tidak berterima.

Makjamai
'bekerja ia

$$
\left\{\begin{array}{c}
\text { a.*lettuk'sampai' } \\
\text { b. *tennga benni } \\
\text { 'tengah malam' }
\end{array}\right\}
$$

Ia bekerja

$$
\left\{\begin{array}{l}
\text { a. } * \text { sampai } \\
\text { b.*tengah malam }
\end{array}\right\}
$$

(52) $\left\{\begin{array}{l}\text { a.*lettuk'sampai' } \\ \text { b.*tennga benni` } \\ \text { tengah malam' }\end{array}\right\} \begin{aligned} & \text { maroak botting éro } \\ & \text { 'ramai pengantin itu' }\end{aligned}$
$\left\{\begin{array}{l}\text { a. *sampai } \\ \text { b. *tengah malam }\end{array}\right\} \begin{aligned} & \text { pesta perkawinan } \\ & \text { itu ramai }\end{aligned}$

Perangkai frasa eksosentris yang menyatakan waktu, antara lain, preposisi ri 'pada', rilalenna 'di dalam', riolona 'sebelum', pura 'sesudah', rimunrinna 'sesudah', mappammula 'mulai', lettuk 'sampai', gangka' hingga'.

Preposisi itu dapat menandai saat tertentu terjadinya serta saat mulai dan berakhirnya peristiwa, keadaan, dan dilakukannya tindakan yang dinyatakan dalam kalimat. Preposisi ri dapat dirangkaikan dengan nama bagian hari (contoh (53).

(53) Siruntukak ambokmu
dénré $\boldsymbol{r i}$
'bertemu saya bapakmu $\quad\left\{\begin{array}{c}\text { élék é 'pagi' } \\ \text { esso é'siang' } \\ \text { subu é 'subuh' }\end{array}\right\}$ tadi pada

'Saya bertemu dengan bapakmu
tadi siang. $\left\{\begin{array}{c}\text { 'pagi.' } \\ \text { subuh.' }\end{array}\right\}$

Preposisi ri 'pada' contoh (53) bersifat tidak wajib (opsional).

Preposisi rilalenna yang berarti 'di dalam' atau 'pada' dapat dirangkaikan dengan leksem waktu seperti contoh berikut.

$$
\begin{array}{r}
\text { ri lalenna ia } \\
\text { di dalam ini }
\end{array} \quad\left\{\begin{array}{l}
\text { wettu é 'waktu' } \\
\text { esso é'hari' } \\
\text { wenni é 'malam }
\end{array}\right\}
$$$$
\left\{\begin{array}{l}
\text { waktu } \\
\text { 'di dalam/pada }
\end{array}\right\} \quad\left\{\begin{array}{l}
\text { hari ini' } \\
\text { malam }
\end{array}\right\}
$$

Penambahan kata ia 'ini' di depan dan partikel é di belakang leksem waktu itu memberikan warna penegasan atau penekanan.

Preposisi riolona yang berarti 'sebelum' dan pura 'sesudah' dapat dirangkaikan dengan nama waktu salat contoh (55).

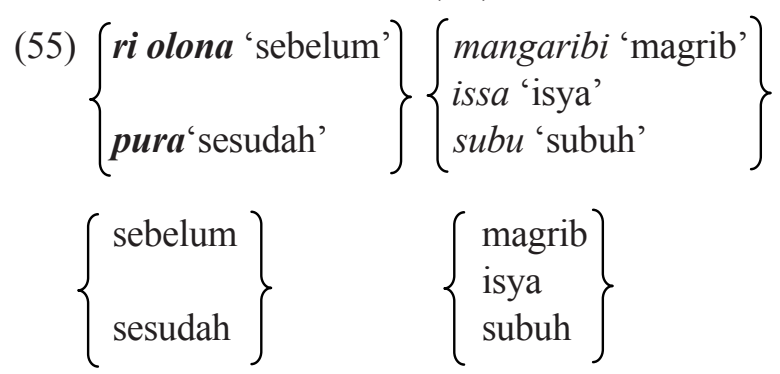

Kata pura 'sesudah' berbeda dengan ri monrinna 'sesudah' karena nama waktu salat yang dirangkaikan dengan ri monrinna harus diikuti partikel é contoh (56) sedangkan pura tanpa diikuti partikel é contoh (55). 
(56)

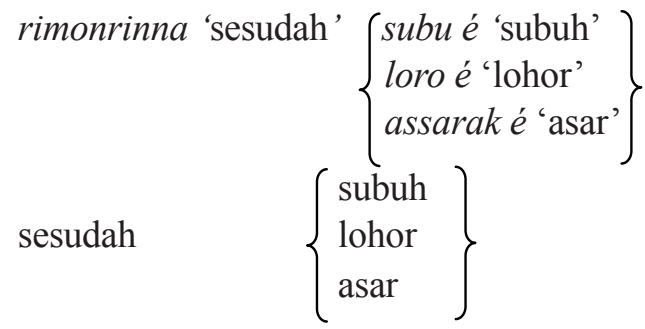

Preposisi mappammula yang bermakna 'sejak' atau 'mulai' menandai titik awal mulainya gerakan waktu, dapat dirangkaikan dengan leksem seperti contoh (57) dan (58).

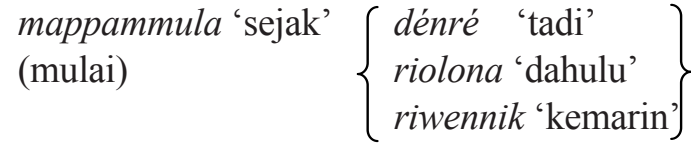

$$
\begin{aligned}
& \begin{array}{l}
\text { sejak } \\
\text { (mulai) }
\end{array} \quad\left\{\begin{array}{l}
\text { tadi } \\
\text { dahulu } \\
\text { kemarin }
\end{array}\right\}
\end{aligned}
$$

Preposisi mappammula tidak dapat dirangkaikan secara langsung dengan satuan kalender minggu 'minggu', uleng 'bulan', dan taung 'tahun'; perangkaiannya memerlukan kata ia 'ini' dan partikel é contoh (58)), tetapi dapat dirangkaikan secara langsung dengan satuan kalender Sinéng 'Senin' dan Ramalang 'Ramadan' contoh (59).

\begin{tabular}{|c|c|}
\hline $\begin{array}{l}\text { mappammula ia } \\
\text { 'mulai ini' }\end{array}$ & $\left\{\begin{array}{l}\text { minggu e'minggu' } \\
\text { uleng e 'bulan' }\end{array}\right.$ \\
\hline mulai & $\left\{\begin{array}{l}\text { minggu ini } \\
\text { bulan ini }\end{array}\right\}$ \\
\hline
\end{tabular}

59) mappammula (essona) Sineng 'hari Senin' 'mulai' $\left\{\begin{array}{l}\text { (uleng) Ramalang } \\ \text { 'bulan Ramadan' }\end{array}\right\}$

'mulai

$$
\left\{\begin{array}{l}
\text { hari Senin' } \\
\text { bulan Ramadan' }
\end{array}\right\}
$$

Preposisi lettuk 'sampai' dan gangka 'hingga' menandai titik henti atau berakhirnya gerakan waktu. Kedua preposisi ini senantiasa dapat saling menggantikan contoh (60).

$$
\begin{aligned}
& \text { (60) } \left.\begin{array}{l}
\text { Lettuk 'sampai' } \\
\text { gangka 'hingga' }
\end{array}\right\}\left\{\begin{array}{l}
\text { wenni 'malam' } \\
\text { dénré 'tadi' } \\
\text { makkokko e'sekarang' }
\end{array}\right\} \\
& \left\{\begin{array}{ll}
\text { malam } \\
\text { sampai } & \begin{array}{l}
\text { tadi } \\
\text { sampai }
\end{array} \\
\text { hingga } & \text { sekarang }
\end{array}\right\}
\end{aligned}
$$

\section{PENUTUP}

Dari hasil penelitian dapat disimpulkan beberapa hal yang berkaitan dengan pernyataan waktu bentuk frasa dalam bahasa Bugis sebagai berikut.

Pernyataan waktu berupa frasa endosentris yang terdiri atas kelompok kata yang berdistribusi paralel dengan salah satu atau semua unsur langsungnya, seperti dalam frasa baja araweng 'besok sore', dan elek yarega wenni 'pagi atau malam'. Rangkaian baja araweng memiliki distribusi yang sama dengan baja, rangkaian elek yarega wenni memiliki distribusi yang sama dengan elek dan wenni. Berdasarkan sifat hubungan unsur-unsur langsungnya, frasa tersebut dapat bersifat atributif, koordinatif, dan apositif.

Selain berbentuk frasa endosentris, pernyataan waktu dalam bahasa Bugis dapat pula berbentuk frasa eksosentris yang sebagian atau seluruhnya tidak memiliki perilaku sintaksis yang sama dengan komponen-komponennya. Sebagai contoh frasa lettuk tennga benni tidak berperilaku yang sama dengan komponen lettukatau tenngabenni.

\section{DAFTAR PUSTAKA}

Alwi, Hasan et al. (1998), Tata Bahasa Baku Bahasa Indonesia. Edisi Ketiga. Jakarta: Balai Pustaka.

Bloomfield, Leonard. (1933), Language. New York: Holt, Reinhart \& Winston, New York.

Djajasudarma, T. Fatimah. (1985), Kala Adverbia Temporal dan Aspek dalam Bambang KaswantiPurwo (Ed.). Jakarta: Arcan.

Fachruddin A.E. et al. (1981), Sastra Lisan Bugis. Jakarta: Pusat Pembinaan dan Pengembangan Bahasa.

Kaswanti Purwo, Bambang(1984), Deiksis dalam Bahasa Indonesia. Edisi Revisi. Seri ILDEP. Jakarta: Balai Pustaka.

Kridalaksana, Harimurti (2008), Kamus Linguistik. Jakarta: PT Gramedia Pustaka Utama. 
Mulya, Abdul Kadir. (1996), Budi Istiharah Indra Bustanul Arifin, Jilid I. Jakarta: Pusat Pembinaan dan Pengembangan Bahasa, Departemen Pendidikan dan Kebudayaan. (1996), Budi IstiharahIndra Bustanul Arifin, Jilid II. Jakarta: Pusat Pembinaan dan Pengembangan Bahasa, Departemen Pendidikan dan Kebudayaan. Putrayasa, Ida Bagus (2010), Analisis Kalimat: Fungsi, Kategori, dan Peran. Bandung: Refika Aditama.
Rijal, Syamsul(2016) Pernyataan Waktu Bentuk Monomorfemik dan Polimorfemik dalam bahasa Bugis. Di dalam Bunga Rampai Hasil Penelitian Bahasa dan Sastra, Volume 22, Nomor 1, Juni 2016, h. 127-138. Makassar: Balai Bahasa Sulawesi Selatan.

Wijana, I Dewa Putu (1987), "Pernyataan Kala dalam Bahasa Indonesia”. Yogyakarta: Tesis Universitas Gadjah Mada. 